\title{
Academic Staff Direct Participation in Managing Higher Education Institutions - Pilot Study Report
}

Katarzyna Szelągowska-Rudzka, Ph.D., Gdynia Maritime University, Faculty of Entrepreneurship and Quality Science,

Poland, ORCID: 0000-0002-8323-7251.

\section{Introduction}

The civilizational challenges faced by the 21 st century knowledge-based economy lead to the increased importance and development of tertiary education and indicate the key role of higher education institutions (HEIs) in this process (Geryk, 2011; Beck-Krala and Klimkiewicz, 2011; Kwiek, 2015; Jakubowska and Rosa, 2011). They require appreciating the role and importance of academic staff as knowledge workers ${ }^{1}$, without whom HEIs would not be able to fulfil its civilizational and social role. The success of organization depends on employees, their competence, engagement and motivation to fulfil their mission, objectives and tasks. Academics are important assets at HEIs; they are carriers of human capital indispensable to build the university competitive advantage (Gwizdała, 2011). Their satisfaction with work and

1 Knowledge workers are people who want to learn and develop, chose places of work providing such opportunity, are focused on learning about novelties, innovation at work, creating the new, gaining satisfaction from work not only thanks to the material benefits and good interpersonal relations, but mainly through achieving success resulting from the implementation of new tasks and projects (Juchnowicz, 2007). 
engagement affects the achievements of HEIs, the level of educational offer and the quality of conducted scientific research (Ryńca, 2014; Grobelna et al., 2016; Kwiek, 2015). The effectiveness of these activities requires employeecentred approach (Daniecki, 1998), instruments for managing human resources (HRM) which ensure the correct use of academic staff potential (human capital) for the development of HEI and the employees themselves (Szelągowska-Rudzka, 2018). According to the author, the academic staff direct participation (ASDP) in managing HEI is an effective instrument to build their engagement in the developing and handling the key areas of HEI activity, i.e. educating students, scientific research development and cooperation with stakeholders (HEI environment) (Leja, 2013). The reference literature provides no studies (research) on ASDP. Therefore, the objective of this study is to present the results of pilot study on academic staff direct participation in managing HEI (content, scope, intensity, practicality of impact), in key areas of its activity, and the related advantages and risks. The study was conducted under direct questionnaire survey method among academic staff in selected HEIs, in autumn 2018.

\section{Academic Staff Direct Participation - essence, forms, advantages and risks}

The employee participation 2 is no new phenomenon. The reference literature has devoted significant attention to the topic, including direct participation, the development of which refers to the development of HRM concept and is still underway (Cierniak-Emerych, 2012; Wilkinson et al., 2013).

The academic staff direct participation means their individual and group participation in all stages of decision-making process at particular level of organizational hierarchy, from the operational scope (position at work) up to HEI strategic scope, related to key areas of its activity (educating students, scientific research development and cooperation with stakeholders (HEI environment), as well as academic staff as the participants and implementors of processes as well as principles and conditions of their activity within HEIs.

The academic staff direct participation may refer to various issues (content of participation, e.g. offering post-graduate studies, commercialization of

2 Concepts: employee participation and participation (direct) of employees in management are treated as synonyms (Cierniak-Emerych, 2012). 
research results), be formalized (based on inter-organizational or superior regulations, e.g. scientific cooperation with other HEIs and enterprises, related to applying for external funding) or non-formalized (based on mutual relations, verbal communication as for suggested actions without their formal grounds, e.g. as per modification of existing subjects). Its intensity, based on the concept by W. Tegtmeier (Mendel, 2002), involves passive approach - cooperation and active approach - co-decision making. The first involves: information from supervisors on the possibility to express opinions, submit motions, and provide advice. The other involves: possibility to oppose, express consent, joint settlement and individual decision making. T. Mendel states that co-decision making proves that the employee direct participation is real; they have real impact on taken decisions. If the employees can only feel the impact exerted during the decision-making process (Piwowarczyk, 2006), which refers to the dominance of cooperation, we observe quasi-participation (perceived) (Mendel, 2002). ASDP may refer to all stages in the decision-making process (tab. 5), and then it takes the form of full participation. Partial participation means participation in any (one) or several stages of decision-making cycle (Moczulska, 2011).

The employee direct participation provides numerous advantages, e.g. in the form of: improved effectiveness and work efficiency, innovative approach of organization, use and development of employee knowledge, their entrepreneurship, engagement, responsibility for organization and results of their activities, understanding of organizational changes and minimizing reluctance, quality of products and customer service, developing human capital, competitive standing in the environment and value for customers (more: Szelągowska-Rudzka, 2016). The risks related to employee direct participation most frequently include: lack of knowledge and motivation among employees to participate and assume more responsibility, short-sighted approach to the issues of organization, time-consuming participation process (Piwowarczyk, 2006).

Taking into account the above-mentioned aspects, the advantages and risks regarding ASDP were identified. The first include: use of academic staff knowledge and their engagement in managing HEIs as well as performing key activities, improved scientific productivity, organizational climate, competitive advantage of HEI in its environment, effectiveness in obtaining external funding, development of scientific research and cooperation with HEIs at home and abroad, implementation projects expected by external stakeholders, adjusting curricula to the needs of business practice. The risks regarding ASDP include: 
lower effectiveness in decision making and responsibility for consequences, participation of incompetent persons, lowered standing and authority of oneperson and collegial HEI bodies, tendency to insist on particularist interests of organizational units or persons, irrational management of HEI financial resources $^{3}$.

\section{Results of Pilot Study}

The pilot study on the academic staff direct participation (ASDP) in managing HEIs was conducted in autumn 2018, among 24 academics, representing economic faculties of five HEIs ${ }^{4}$. The selection was intentional. The survey was undertaken by workers from the Faculty of Entrepreneurship and Quality Science of GMU, who were invited to do so and workers from the other universities known to the Author, whose area of professional interest lies within management sciences and who agreed to take part in the survey. The majority of respondents were women (17 people), people with doctoral degree (18; $5 \mathrm{dr}$ hab. and one professor), employed as academic staff (19 people), people without managerial position (21 people), mostly aged $35-55$ (20 people; aged more than $56-4$ people) and seniority of $21-30$ years (13 people; $10-20$ years -8 people; $41-50$ years - 2 people; 31-40 years -1 person).

The direct questionnaire survey was applied as research method. The questionnaire (data collection instrument) included closed-end questions regarding: the content and scope of ASDP in key areas of HEI activity, stages in decision-making process, intensity and practicality of participation and the related advantages and risks. The results are presented in tables 1-10.

3 Employee direct participation involves various techniques related to its individual and group form (Moczulska 2011). It is determined by internal and external factors (Cierniak-Emerych, 2012). However, they are not covered in this study. They will be included in in-depth studies on ASDP.

4 Including: Gdynia Maritime University (15 people), Wrocław University of Economics (5 people), University of Rzeszów (2 people), Maria Curie-Skłodowska University in Lublin and University of Zielona Góra (1 person each). 
Table 1. Respondents' opinion on whether academic staff should participate directly in managing HEI in particular areas of its activity

\begin{tabular}{l|c|c|c|c|c}
\hline \multirow{2}{*}{ Key areas of activity } & \multicolumn{5}{|c}{ Answers } \\
\cline { 2 - 7 } & $\begin{array}{c}\text { Definitely } \\
\text { yes }\end{array}$ & Yes & $\begin{array}{c}\text { Difficult } \\
\text { to say }\end{array}$ & No & $\begin{array}{c}\text { Definitely } \\
\text { not }\end{array}$ \\
\hline Educating students & 7 & 8 & 9 & 0 & 0 \\
\hline Science development & 4 & 8 & 11 & 1 & 0 \\
\hline Developing relations with the environment & 5 & 13 & 5 & 1 & 0 \\
\hline
\end{tabular}

Source: own study based on the research results

According to the majority of respondents, academic staff should directly participate in the process of HEI management, in particular in building relations with the environment - 18 answers (yes and definitely yes) and educating students - 15 answers (ditto). To a lesser extent in the development of science 12 respondents (tab. 1$)$.

Table 2. Respondents' opinion on their direct participation in educating students

\begin{tabular}{l|c|c|c|c|c|c}
\hline Participation in designing, im- & \multicolumn{5}{c}{ Answers } \\
$\begin{array}{l}\text { proving and adjusting the offer } \\
\text { to the needs of HEI environment } \\
\text { (stakeholders) regarding: }\end{array}$ & $\begin{array}{c}\text { Very } \\
\text { high }\end{array}$ & High & $\begin{array}{c}\text { Difficult } \\
\text { to say }\end{array}$ & Low & $\begin{array}{c}\text { Very } \\
\text { low }\end{array}$ & $\begin{array}{l}\text { No parti- } \\
\text { ci-pation }\end{array}$ \\
\cline { 4 - 8 } & 2 & 8 & 4 & 4 & 2 & 4 \\
\hline a) post-graduate studies & 1 & 5 & 2 & 7 & 6 & 3 \\
\hline b) fields of study & 3 & 13 & 2 & 6 & 0 & 0 \\
\hline c) specialties & 10 & 9 & 3 & 2 & 0 & 0 \\
\hline
\end{tabular}

Source: own study based on the research results

The direct participation of the surveyed in managing HEIs is relatively highest within the area of teaching (tab. 2), the lowest - within the area of science (tab. 3). As for educating students - it refers mainly to offering and improving subjects adjusted to the needs of economic practice - 19 answers (high, very high) and specialty - 16 (ditto). It least frequently refers to the fields of study - 13 (low, very low) (tab. 2). 
Table 3. Respondents' direct participation in science development - in the light of given answers

\begin{tabular}{l|c|c|c|c|c|c}
\hline $\begin{array}{l}\text { Participation in scientific cooperation, } \\
\text { submitting joint scientific projects and } \\
\text { applying for external funding (e.g. } \\
\text { NCN, NCBiR) with collaborators from: }\end{array}$ & $\begin{array}{c}\text { Very } \\
\text { high }\end{array}$ & High & $\begin{array}{c}\text { Difficult } \\
\text { to say }\end{array}$ & Low & $\begin{array}{c}\text { Very } \\
\text { low }\end{array}$ & $\begin{array}{l}\text { No parti- } \\
\text { ci-pation }\end{array}$ \\
\hline a) own HEI (e.g. department, faculty) & 2 & 5 & 2 & 4 & 7 & 4 \\
\hline b) other national HEIs & 0 & 2 & 2 & 6 & 5 & 9 \\
\hline c) foreign HEIs & 0 & 3 & 1 & 2 & 8 & 10 \\
\hline $\begin{array}{l}\text { Participation in research results commer- } \\
\text { cialization }\end{array}$ & 0 & 2 & 1 & 3 & 7 & 11 \\
\hline
\end{tabular}

Source: own study based on the research results

Table 4. Direct participation of the surveyed in developing relations with HEI environment in the following areas

\begin{tabular}{l|c|c|c|c|c|c}
\cline { 2 - 6 } & \multicolumn{5}{c}{ Answers } \\
\cline { 2 - 7 } & $\begin{array}{c}\text { Very } \\
\text { high }\end{array}$ & High & $\begin{array}{c}\text { Difficult } \\
\text { to say }\end{array}$ & Low & $\begin{array}{c}\text { Very } \\
\text { low }\end{array}$ & $\begin{array}{c}\text { No parti- } \\
\text { cipation }\end{array}$ \\
\hline $\begin{array}{l}\text { Initiating and implementing joint de- } \\
\text { velopment projects with enterprises, } \\
\text { regional authorities etc. by encouraging } \\
\text { external stakeholders to: offer particular } \\
\text { subjects, specialties, fields } \\
\text { of study, post-graduate studies dedicat- } \\
\text { ed to particular sectors, organisations } \\
\text { and their groups }\end{array}$ & 0 & 5 & 3 & 4 & 4 & 8 \\
\hline $\begin{array}{l}\text { Submitting proposals for improvements, } \\
\text { organizational changes to engage } \\
\text { academic staff in developing and } \\
\text { adjusting scientific research and teaching } \\
\text { to the needs of HEI environment }\end{array}$ & 0 & 5 & 5 & 6 & 2 & 6 \\
\hline
\end{tabular}

Source: own study based on the research results

As for direct participation of the surveyed in decisions related to developing relations with external stakeholders significant number of answers referred 
to - no participation, low and very low participation regarding joint educational projects -8 and within submitting proposals for improvements in teaching and development of science resulting in their adjustment to the needs of HEI environment - 8 (tab. 4). In the case of science development, the respondents marked mostly - low and very low participation and no participation in the commercialization of research results - 11 people, and scientific cooperation, financed with external funds, with foreign scientists - 10 people and with domestic scientists - 9 people. The relatively highest level of ASDP was recorded within scientific cooperation with employees from other organizational units of home HEIs - 7 answers (high, very high) (tab. 3).

Table 5. Academic staff direct participation in particular stages of decision-making process

\begin{tabular}{l|c|c|c|c|c}
\hline \multirow{2}{*}{ Stages in decision-making process } & \multicolumn{5}{|c}{ Frequency of participation } \\
\cline { 2 - 6 } & $\begin{array}{c}\text { Very } \\
\text { often }\end{array}$ & Often & $\begin{array}{c}\text { Difficult } \\
\text { to say }\end{array}$ & Rarely & $\begin{array}{c}\text { Very } \\
\text { rarely }\end{array}$ \\
\hline $\begin{array}{l}\text { Participation in issue identification/need for } \\
\text { improvement }\end{array}$ & 1 & 5 & 6 & 5 & 7 \\
\hline $\begin{array}{l}\text { Collection of information on problematic } \\
\text { situation/ } \\
\text { need for improvement }\end{array}$ & 0 & 6 & 3 & 7 & 8 \\
\hline $\begin{array}{l}\text { Seeking solutions } \\
\text { Participation in assessing and choosing poten- } \\
\text { tial solutions }\end{array}$ & 0 & 3 & 2 & 10 & 9 \\
\hline $\begin{array}{l}\text { Participation in implementing selected solu- } \\
\text { tions }\end{array}$ & 1 & 5 & 3 & 10 & 5 \\
\hline
\end{tabular}

Source: own study based on the research results

The respondents participate in all stages of decision-making process in the key areas of HEI activity. However, they mark the frequency of participation as rare and very rare, regarding in particular: assessing and choosing solutions 19 answers and implementing the selected solution -15 answers. The surveyed most frequently participate directly in seeking solutions -8 (often, very often) (tab. 5). 
Table 6. Intensity of the surveyed academic staff direct participation regarding the area of teaching ${ }^{5}$

\begin{tabular}{l|c|c|c|c|c|c|c|c}
\hline \multirow{2}{*}{$\begin{array}{l}\text { Participation in de- } \\
\text { signing, improving } \\
\text { and adjusting the } \\
\text { offer to the needs of } \\
\begin{array}{l}\text { HEI environment } \\
\text { (stakeholders): }\end{array}\end{array}$} & $\begin{array}{c}\text { Nature of direct participation } \\
\text { Informa- } \\
\text { the supe- } \\
\text { riors }\end{array}$ & $\begin{array}{c}\text { Possibility } \\
\text { to express } \\
\text { opinions, } \\
\text { submit mo- } \\
\text { tions }\end{array}$ & $\begin{array}{c}\text { Ad- } \\
\text { vising }\end{array}$ & $\begin{array}{c}\text { Pos- } \\
\text { sibility } \\
\text { to op- } \\
\text { pose }\end{array}$ & $\begin{array}{c}\text { Ex- } \\
\text { press- } \\
\text { ing } \\
\text { consent }\end{array}$ & $\begin{array}{c}\text { Joint } \\
\text { set- } \\
\text { tle- } \\
\text { ment }\end{array}$ & $\begin{array}{c}\text { Indivi- } \\
\text { dual } \\
\text { deci- } \\
\text { sion } \\
\text { making }\end{array}$ & $\begin{array}{c}\text { No } \\
\text { par- } \\
\text { ticipa- } \\
\text { tion }\end{array}$ \\
\hline a) post-graduate & 3 & 10 & 6 & 4 & 3 & 7 & 3 & 10 \\
\hline studies & 11 & 10 & 5 & 3 & 4 & 4 & 0 & 6 \\
\hline b) fields of study & 5 & 20 & 12 & 8 & 7 & 10 & 1 & 3 \\
\hline d) subjects & 6 & 17 & 15 & 5 & 8 & 14 & 9 & 1 \\
\hline
\end{tabular}

Source: own study based on the research results

Table 7. Intensity of the respondents' direct participation in science development5

\begin{tabular}{l|c|c|c|c|c|c|c|c}
\hline $\begin{array}{l}\text { Participation in scien- } \\
\text { tific cooperation, sub- } \\
\text { mitting joint scientific } \\
\text { projects and applying } \\
\text { for external funding } \\
\text { (e.g. NCN, NCBiR) with } \\
\text { collaborators from: }\end{array}$ & $\begin{array}{c}\text { Infor- } \\
\text { mation } \\
\text { from the } \\
\text { superi- } \\
\text { ors }\end{array}$ & $\begin{array}{c}\text { Possibility } \\
\text { to express } \\
\text { opinions, } \\
\text { submit } \\
\text { motions }\end{array}$ & $\begin{array}{c}\text { Ad- } \\
\text { vising }\end{array}$ & $\begin{array}{c}\text { Possi- } \\
\text { bility to } \\
\text { oppose }\end{array}$ & $\begin{array}{c}\text { Ex- } \\
\text { press- } \\
\text { ing } \\
\text { consent } \\
\text { mettle- } \\
\text { ment }\end{array}$ & $\begin{array}{c}\text { Joint } \\
\text { seture of direct participation } \\
\text { dual } \\
\text { deci- } \\
\text { sion } \\
\text { making }\end{array}$ & $\begin{array}{c}\text { No } \\
\text { par- } \\
\text { tici- } \\
\text { pa- } \\
\text { tion }\end{array}$ \\
\hline $\begin{array}{l}\text { a) own HEI (e.g. } \\
\text { department, faculty) }\end{array}$ & 7 & 11 & 8 & 2 & 6 & 8 & 4 & 10 \\
\hline $\begin{array}{l}\text { b) other national HEIs } \\
\text { b) foreign HEIs }\end{array}$ & 6 & 2 & 1 & 0 & 1 & 1 & 1 & 13 \\
\hline $\begin{array}{l}\text { Participation in } \\
\text { research results } \\
\text { commercialization }\end{array}$ & 6 & 3 & 4 & 1 & 1 & 3 & 1 & 13 \\
\hline
\end{tabular}

Source: own study based on the research results

5 Respondents could indicate any number of answers. 
As for the intensity of ASDP in taking decisions on key areas of HEI activity it has been indicated that passive participation is dominant in each area of activity (information from the superiors, possibility to express opinions, submitting motions, advising) (tab. 6, 7, 8). The relatively highest level of active participation (possibility to oppose, expressing consent, joint settlement, individual decision making) was marked by the respondents in educating students, and in particular with reference to subjects (the majority in this study - 9 answers for individual decision making) (tab. 6). The other areas, active participation is relatively significant as for scientific cooperation with the employees of own HEI (20, tab. 7) and as for submitting proposals for improvement in scientific research and teaching dedicated to HEI environment (17, tab. 8). Particularly large number of answers - no participation - is also significant (much larger compared to answers related to the total level of participation, tab. 3) as for assessing the intensity of ASDP in taking decisions on science development (tab. 7).

Table 8. Intensity of direct participation of the surveyed in developing relations with $\mathrm{HEI}$ environment5

\begin{tabular}{|c|c|c|c|c|c|c|c|c|}
\hline & \multicolumn{7}{|c|}{ Nature of direct participation } & \multirow[b]{2}{*}{$\begin{array}{l}\text { No } \\
\text { par- } \\
\text { tici- } \\
\text { pa- } \\
\text { tion }\end{array}$} \\
\hline & $\begin{array}{l}\text { Informa- } \\
\text { tion from } \\
\text { the supe- } \\
\text { riors }\end{array}$ & $\begin{array}{c}\text { Possibility } \\
\text { to express } \\
\text { opinions, } \\
\text { submit } \\
\text { motions }\end{array}$ & $\begin{array}{c}\text { Ad- } \\
\text { vising }\end{array}$ & \begin{tabular}{|c|} 
Pos- \\
sibil- \\
ity to \\
oppose
\end{tabular} & $\begin{array}{c}\text { Expre- } \\
\text { ssing } \\
\text { con- } \\
\text { sent }\end{array}$ & $\begin{array}{c}\text { Joint } \\
\text { set- } \\
\text { tle- } \\
\text { ment }\end{array}$ & \begin{tabular}{|c|} 
Indivi- \\
dual \\
deci- \\
sion \\
making
\end{tabular} & \\
\hline $\begin{array}{l}\text { Initiating and imple- } \\
\text { menting joint develop- } \\
\text { ment projects with } \\
\text { companies, regional } \\
\text { authorities, etc. through } \\
\text { encouraging external } \\
\text { stake-holders to: submit } \\
\text { proposals of particular } \\
\text { subjects, specialties, } \\
\text { fields of study, post- } \\
\text { graduate studies } \\
\text { dedi-cated to particular } \\
\text { sectors/ organisations, } \\
\text { their groups }\end{array}$ & 10 & 8 & 6 & 1 & 4 & 5 & 0 & 8 \\
\hline
\end{tabular}


Submitting improvements, organizational changes to engage academic staff in developing and adjusting scientific research and teaching to the needs of HEI environment

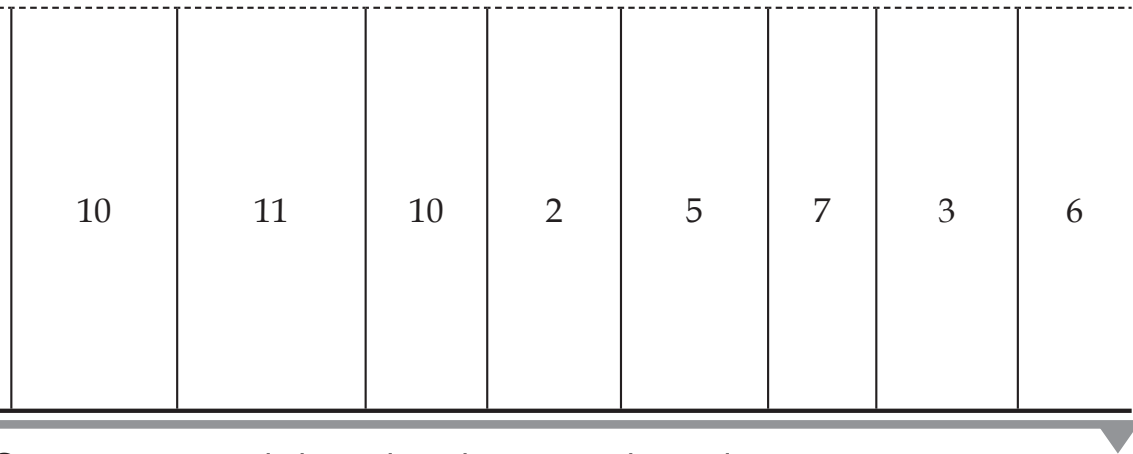

Source: own study based on the research results

The surveyed were rather sceptical as for potential benefits from ASDP at their HEIs, which is proven by significant number of answers - difficult to say, low, very low. It mainly refers to: better effectiveness of HEIs in obtaining external funding - 22 answers (ditto), development of scientific cooperation with foreign universities - 21 and improvement in the competitive standing of HEI in the environment - 19. The surveyed indicate relatively greatest benefits resulting from PBNA in adjusting curricula to the needs of economic practice - 11 (high) and in using knowledge of academic staff, their engagement in managing HEIs and in handling key areas of activity - 10 (high, very high), which is particularly important for the perspective of commenced research analyses (tab. 9).

Table 9. Assessing by the respondents the level of advantages resulting from ASDP in their HEls

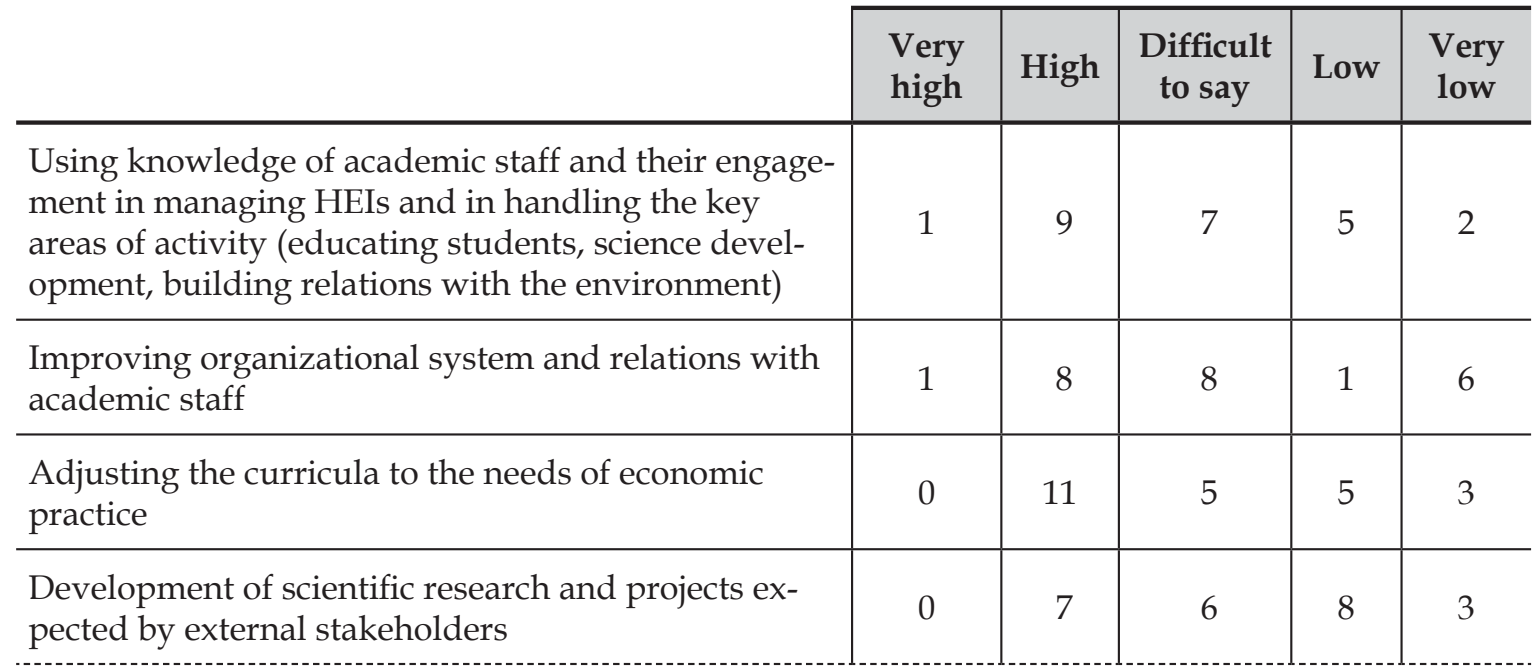




\begin{tabular}{l|l|l|l|l|l}
\hline $\begin{array}{l}\text { Development of scientific cooperation with other } \\
\text { home HEIs }\end{array}$ & 0 & 5 & 9 & 7 & 3 \\
\hline $\begin{array}{l}\text { Development of scientific cooperation with foreign } \\
\text { universities }\end{array}$ & 0 & 3 & 7 & 9 & 5 \\
\hline $\begin{array}{l}\text { Improvement of scientific productivity of academic } \\
\text { staff }\end{array}$ & 0 & 5 & 8 & 6 & 5 \\
\hline $\begin{array}{l}\text { Improvement of the university competitive standing } \\
\text { in the environment }\end{array}$ & 1 & 4 & 10 & 6 & 3 \\
\hline $\begin{array}{l}\text { Better effectiveness of HEI in obtaining external } \\
\text { funding }\end{array}$ & 0 & 2 & 14 & 5 & 3 \\
\hline
\end{tabular}

Source: own study based on the research results

Table 10. Opinion of the surveyed academic staff on the level of risks they identify regarding ASDP at their HEIs

\begin{tabular}{l|c|c|c|c|c}
\cline { 2 - 6 } & $\begin{array}{c}\text { Very } \\
\text { high }\end{array}$ & High & $\begin{array}{c}\text { Difficult } \\
\text { to say }\end{array}$ & Low & $\begin{array}{c}\text { Very } \\
\text { low }\end{array}$ \\
\hline Lower effectiveness in taking decisions & 3 & 2 & 10 & 6 & 3 \\
\hline Reduced responsibility for decisions taken & 3 & 3 & 8 & 9 & 1 \\
\hline $\begin{array}{l}\text { Weakened position and authority of one-person } \\
\text { and collegial HEI bodies }\end{array}$ & 2 & 2 & 9 & 8 & 3 \\
\hline $\begin{array}{l}\text { Tendency to insist on particularist interests of } \\
\text { organizational units (departments) or people }\end{array}$ & 5 & 10 & 7 & 2 & 0 \\
\hline \begin{tabular}{l} 
Irrational management of HEI financial resources \\
\hline $\begin{array}{l}\text { Incompetent persons' participation in decision- } \\
\text { making process }\end{array}$
\end{tabular} & 4 & 3 & 12 & 4 & 1 \\
\hline
\end{tabular}

Source: own study based on the research results

The surveyed academics most often do not have opinion on risks or indicate low level of risks regarding ASDP in managing HEIs (difficult to say, low, very low). They indicate relatively most significant risk regarding the tendency to insist on particularist interests of organizational units or persons - 15 answers (high, very high) (tab. 10). 


\section{Conclusions and Discussion}

The conducted pilot study indicated the direct participation of the surveyed academic staff in managing their HEIs. The participation:

- refers to all key areas of HEI activity,

- is most visible in educating students, then in building relations with the HEI environment (stakeholders), is least visible in science development,

- is operational since the surveyed most often directly participate in decisions related to teaching (their basic obligations), in particular designing, improving and modifying the subjects and specialties, rarely in issues related to HEI strategic development plan (e.g. participation in scientific cooperation with the representatives of foreign universities and based on external funding),

- is full since the respondents participate in all stages of decision-making process, but at different frequency,

- takes passive form (of cooperation) in all key areas of activity (active form is definitely less frequent), which indicates that it is perceived, and not real participation,

- does not generate significant negative consequences; the largest identified risk is the tendency to insist on particularist interests of organizational units (departments) or people,

- the largest benefits indicated by the respondents include: adjusting curricula to the needs of economic practice and using knowledge of academic staff and their engagement in managing HEIs and in handling its key areas of activity. The last statement is particularly important for the subject of this study. It indicates the direct participation as an instrument to engage academic staff in the HEI development, building its competitive standing in the environment. ASDP refers mainly to teaching and building relations with HEI environment, including employers waiting for graduates to enter the labour market; graduates who meet the expectations of modern knowledge-based economy. The result is well-grounded - and more and more important are the main benefits resulting from ASDP, indicated by the surveyed - since it refers to the key educational role in HEI activity and the role of HEIs in the social and economic system in the country (Sułkowski, 2016; Leja, 2013; Kwiek, 2015).

ASDP occurs in all three key areas of HEI activity and in all stages of decisionmaking process (full participation). However, it is thought-provoking that the more in-depth insight in the issue - assessment of its intensity - the respondents are more inclined to indicate in their answers - no participation. Perhaps, after deeper thought about the answers the surveyed review their first, spontaneous 
answers. On the other hand, the advantage of cooperation (passive form) over co-decision making (active form), detected in the survey, indicate that direct participation of the surveyed in managing their HEIs takes the quasi-participatory form, and not the form of real participation (Mendel, 2002), and as a result, the practicality of its impact on HEI management is limited. This conclusion is confirmed by the results of M. Kwiek's research proving that the Polish academic staff has little impact (44\% of professors) or has no impact (junior staff $-78.7 \%$ ) on "policy-making” at their HEIs. Moreover, junior academics positively assess the previous method of informing (weakest form of participation, Piwowarczyk, 2006) on the daily issues at HEIs, and do not see the need to be more engaged in the activities of their alma mater (contrary to the professors) (Kwiek, 2015, p. 286).

The obtained results as well as weaknesses of the HEI management system in Poland (Kwiek, 2015; Sulkowski, 2016b), including the area of HRM (Sułkowski, 2016b, Szelągowska-Rudzka, 2018), suggest preliminary (to be confirmed under more in-depth studies) conclusion indicating insufficient use, on the part of HEIs, of the potential of academic staff - as knowledge workers of particular professional competences (knowledge, skills, experience and contact with the HEI external environment) for the development, implementation of mission, objectives and strategy of HEIs.

The obtained results may also indicate that not all academics have internal motivation to participate in decision-making regarding HEIs and take responsibility for them (the opinion of superiors). This reluctant approach may result from insufficient efficiency incentives (motivation system) encouraging employees to be more engaged in the HEI matters. Nobody can be forced to participate but it worth providing good conditions to do so - improve instruments for human resources management - to engage people with potential and motivation, which will bring benefits to them and HEIs.

Although the conducted study is a pilot study (is not representative), it provides interesting conclusions and observations on the need to conduct more in-depth studies on ASDP, its standing, related to advantages and risks, as well as identification and diagnosis of the direction and impact of internal (e.g. motivation system) and external determinants (e.g. needs of external stakeholders) of the said participation and its particular aspects (techniques). The author intends to undertake such research on the basis of interpretive and qualitative paradigm of the research approach, which makes it possible to comprehend the reality in such a form, in which it is perceived by its participants (Jemielniak, 2012a). She is planning to apply a case study 
as the research strategy (Jemielniak 2012b) selecting cases to her research from public and non-public economic universities (about 4) (Czakon, 2015) and their organisational units (cases inside the case) relating in their subject to management sciences. Thus, "the maximum variety (the ownership form, sources of financing/funding, the position on the market) will be ensured with the maximum comparability" (economic universities, management sciences). The use of triangulation of the research qualitative methods (focused on group interviews, individual interviews, nonparticipant direct observation, documentation analysis) and the quantitative research methods (direct questionnaire) will allow the Author to obtain consistency of empirical bases and conclusions, to explain thoroughly and familiarise the subject of the research (Czakon, 2015). A certain constraint is the implementation of the Law on Higher Education and Science, which changes the conditions, in which the university operates. Therefore, the research will have conducted by that time.

\section{Summary}

The conducted study is a pilot study, is not representative; however, it helps to determine that we can observe the direct participation of academic staff in managing the analysed HEIs. This is full participation (it refers to all stages in decision-making process), and its content includes key areas of HEI activity (educating students, science development, building relations with the environment). It has operational scope (small, strategic), and is concentrated on basic tasks of academic staff related to teaching. Its passive form is dominant - cooperation (information from superiors, possibility to express opinion, submit motions and advising), which indicates that it is perceived and not real participation, and the practicality of impact of the surveyed on the process of managing HEI is limited. Since the respondents indicated the adjustment of curricula to the needs of economic practice and the use of knowledge of academic staff and its engagement in managing HEI and in handling the key areas of its activity as the main advantages resulting from ASDP, it can be concluded that ASDP can become an effective instrument of engaging academics into developing HEIs and building their competitive standing. However, it requires developing this participation as well as instruments for managing human resources correlated with mission, objectives and strategy of HEI activity, and further in-depth studies the author is planning for the future. 
Abstract

Academic Staff Direct Participation in Managing Higher Education Institutions - Pilot Study Report

The aim of the study is to present the results of pilot study on academic staff direct participation (ASDP) in managing higher education institutions (HEI) (content, scope, intensity, practicality of impact), in key areas of its activity and its advantages and risks. The research was carried out under questionnaire survey method among academic staff of selected HEIs, in autumn 2018. It was found that ASDP applies to all areas of activity of these HEIs (content), primarily educating students; is full (academics participate in all stages of the decision-making process), has mainly operational scope (related to basic tasks in the position at work), less often strategic; it is perceived participation because the real impact of the respondents in managing HEIs is limited (passive form of participation dominates). The identified main benefits from participation indicate that ASDP can be an effective tool for creating commitment of academic staff in managing HEIs in handling their key areas of activity. The results presented are not representative (pilot study), but interesting. Therefore, the author is planning to carry out in-depth research on ASDP in managing HEI in the future.

Keywords: academic staff direct participation (ASDP), forms of direct participation, advantages and disadvantages of ASDP.

\section{Streszczenie}

Partycypacja bezpośrednia nauczycieli akademickich w zarządzaniu uczelnią - komunikat z badania pilotażowego

Celem opracowania jest prezentacja wyników badania pilotażowego dotyczącego partycypacji bezpośredniej nauczycieli akademickich (PBNA) w zarządzaniu uczelnią (treść, zakres, intensywność, realność wpływu), w kluczowych obszarach jej działalności oraz związanych z nią korzyści i zagrożeń. Badanie zrealizowano metodą ankietową wśród nauczycieli akademickich wybranych uczelni, jesienią 2018 r. Stwierdzono, że PBNA dotyczy wszystkich obszarów działalności tych uczelni (treść), przede wszystkim dydaktyki; jest pełna (akademicy 
uczestniczą we wszystkich etapach procesu podejmowania decyzji), ma głównie zakres operacyjny (odnoszący się do podstawowych zadań na stanowisku), rzadziej strategiczny; jest to partycypacja postrzegana, gdyż realny wpływ badanych na zarządzanie uczelnia jest ograniczony (dominuje forma bierna partycypacji - współdziałanie). Zidentyfikowane główne korzyści z partycypacji wskazują, że PBNA może być skutecznym instrumentem kształtowania zaangażowania kadry akademickiej $\mathrm{w}$ zarządzanie uczelnią i $\mathrm{w}$ realizację jej głównych obszarów działalności. Zaprezentowane wyniki nie są reprezentatywne (badanie pilotażowe), ale interesujące. Dlatego autorka zrealizuje w przyszłości badania pogłębione nad PBNA w zarządzaniu uczelnią.

\section{Słowa}

kluczowe: partycypacja bezpośrednia nauczycieli akademickich (PBNA), formy partycypacji, korzyści i zagrożenia zwiazane z PBNA.

JEL

Classification: M12, I23

\section{References}

1. Beck-Krala, E., Klimkiewicz, K. (2011). W kierunku kształtowania świadomej polityki społecznej odpowiedzialności uczelni wyższych, Prace Naukowe Uniwersytetu Ekonomicznego we Wroctawiu, No. 220, pp. 234-247.

2. Cierniak-Emerych, A. (2012). Uczestnictwo pracobiorców w gospodarowaniu potencjatem pracy w przedsiębiorstwie, Wrocław: Wydawnictwo Uniwersytetu Ekonomicznego we Wrocławiu.

3. Czakon W. (red.) (2015), Podstawy metodologii badań w naukach o zarządzaniu, Wyd. 3 rozszerzone, Warszawa: Oficyna a Wolters kluwer.

4. Geryk, M. (2011). Social Responsibility of Higher Education Institutions as Manifestation of Positive Organisational Scholarship, Journal of Positive Management, Vol. 2, No. 1, pp. 15-24.

5. Grobelna, A., Sidorkiewicz, M., Tokarz-Kocik, A., (2016). Job Satisfaction Among Hotel Employees: Analyzing Selected Antecedents And Job Outcomes. A Case Study From Poland, ARGUMENTA OECONOMICA, No. 2 (37), pp. 281-310.

6. Gwizdała, J. (2011). Kapitał intelektualny w zarzadzaniu szkoła wyższą - dylematy [in:] J. Dworak, J. Jaworski (ed.), Zarządzanie szkołą wyższą. 
Dylematy i wyzwania, Prace Naukowe Wyższej Szkoły Bankowej w Gdańsku, t. 14, pp. 243-255.

7. Jakubowska, A., Rosa, A. (2011). Znaczenie szkolnictwa wyższego w gospodarce opartej na wiedzy [in:] J. Dworak, J. Jaworski (ed.), Zarządzanie szkołą wyższą. Dylematy i wyzwania, Prace Naukowe Wyższej Szkoły Bankowej w Gdańsku, vol. 14, pp. 63-79.

8. Jemielniak, D. (ed.) (2012a). Badania jakościowe. Podejścia i teorie. Warszawa: Wydawnictwo Naukowe PWN.

9. Jemielniak, D. (ed.) (2012b). Badania jakościowe. Metody i narzędzia. Warszawa: Wydawnictwo Naukowe PWN.

10. Juchnowicz, M. (ed.) (2007). Elastyczne zarzadzanie kapitatem ludzkim w organizacji wiedzy, Warszawa: Difin.

11. Kwiek, M. (2015). Uniwersytet w dobie przemian, Warszawa: PWN.

12. Leja, K. (2013). Zarządzanie uczelnia. Koncepcje i wspótczesne wyzwania, Wyd. II uzupełnione, Warszawa: Wolters Kluwer business.

13. Mendel, T. (2002). Partycypacja w zarządzaniu wspótczesnymi organizacjami, Wyd. II, Poznań: Wydawnictwo Akademii Ekonomicznej w Poznaniu.

14. Moczulska, M. (2011), Bezpośrednia partycypacja pracowników w zarządzaniu przedsiębiorstwem. Możliwości, przesłanki, uwarunkowania, Zielona Góra: Oficyna Wydawnicza Uniwersytetu Zielonogórskiego.

15. Piwowarczyk, J. (2006). Partycypacja w zarządzaniu a motywowanie pracowników, Warszawa: Wydawnictwo Oficyna Ekonomiczna.

16. Ryńca, R. (2014). Zastosowanie wybranych metod i narzędzi w ocenie dziatalności szkoły wyższej, Wrocław: Oficyna Wydawnicza Politechniki Wrocławskiej.

17. Sułkowski, Ł. (2016a). Kultura akademicka. Koniec utopii?, Warszawa: PWN.

18. Sułkowski, Ł. (2016b). Zarządzanie kapitałem ludzkim w polskich uczelniach, Prace Naukowe Uniwersytetu Ekonomicznego we Wroctawiu, No. 429, pp. 269-279.

19. Szelągowska-Rudzka, K. (2016). Employee direct participation - the essence and advantages, Zeszyty Naukowe Akademii Morskiej w Gdyni. Joint Proceedings, Hochschlue Bremerhaven - Akademia Morska w Gdyni, No. 94, pp. 60-72.

20. Szelągowska-Rudzka, K. (2018). Human Resources Management in Higher Education Institu-tions in Poland, Management, Vol. 22, No. 1, pp. 208-225, DOI:10.2478/manment-2018-0015.

21. Wilkinson, A., Dunton, T., Marchington, M. (2013). Employee Involvement and Voice, [in:] S. Bach, M. R. Edwards (eds.), Managing Human Resources: Human Resource Management in Transition, Fifth Edition, Wiley, UK, 2013. 